\title{
Liudmila Ulitskaia's Literature of Tolerance
}

\author{
BENJAMIN MASSEY SUTCLIFFE
}

$\mathrm{W}$ hen Liudmila Ulitskaia published The Funeral Party in 1997 the novella received the critical scrutiny warranted by the latest work of an already prominent figure in postSoviet letters. The plot, set in New York in the humid summer of 1991, revolves around the dying artist Alik and the crowd of friends, former and present lovers, and chance acquaintances gathering in his Chelsea loft. Booker Prize laureate Ol'ga Slavnikova misdiagnoses this narrative as an engaging failure: it attempts to achieve the impossible by trying to fill the void left by the deceased. ${ }^{1}$

Not surprisingly, Ulitskaia's own description of the novella provides an alternate view: "This is a book about a person who has done everything possible so that after his departure there will not be a black hole of despair, but an atmosphere of reconciliation and love." ${ }^{2}$ The author's assessment is more than a commonplace designed to snare sensitive readersit is a key to her prose and plays, shaping The Funeral Party and culminating in Daniel Stein, Interpreter (2006), a structurally heterogeneous novel about healing the rift between Jews and gentiles. ${ }^{3}$ These two works powerfully depict the results of misunderstanding and, more significantly in the context of Russian culture, stress the need for reconciliation. Both narratives foreground Ulitskaia's longstanding fascination with hybrid characters: those individuals who combine different (and usually divisive) ethnicities and belief systems. Such characters and their roles in these two novels suggest the main concern of her oeuvretolerance as the practice of acknowledging and engaging the conflicting viewpoints that, as Isaiah Berlin reminds us, form everyday experience. ${ }^{4}$

The author thanks four generous colleagues at Miami University-Vitaly Chernetsky, Mila Ganeva, Nicole Thesz, and Margaret Ziolkowski-for their comments on an earlier draft of this article. Likewise, Michael Gorham and two anonymous reviewers at The Russian Review provided detailed and sensible suggestions for the present study.

'On The Funeral Party see Ol'ga Slavnikova, "Nedolet ukazyvaet na tsel'," Ural, 1999, no. 2:185. For a similar view see Volodia Iuzbashev, "L. Ulitskaia: Veselye pokhorony," Znamia, 1998, no. 11:66. All translations are my own unless otherwise indicated.

${ }^{2}$ Liudmila Ulitskaia, Veselye pokhorony (1997; reprint ed. Moscow, 2006), cover flap.

${ }^{3}$ Ulitskaia, Daniel' Shtain, perevodchik (Moscow, 2006).

${ }^{4}$ Isaiah Berlin, "The Pursuit of the Ideal," in Moral Disagreements: Classical and Contemporary Readings (London, 2000), 199-200. The importance Ulitskaia attaches to tolerance likewise recalls one of Karl Popper's axioms for an open society. This community promotes "tolerance toward all who are not intolerant and who do not propagate intolerance." Popper wrote this seminal work in 1943 and revised it in 1950, when Stalinism 
The problem of conflating author and fiction notwithstanding, it is important to remember that Ulitskaia herself is a Jew who has converted to Russian Orthodoxy. As Judith Kornblatt has shown, this tendency, which had a small but highly visible presence in the late- and post-Soviet intelligentsia, was interpreted by some converts as being "doubly chosen"-belonging to the Chosen People yet electing to become a Christian. Likewise, Ulitskaia has developed a series promoting tolerance among young readers - to a certain degree her life validates the Russian literary tradition's proclivity for seeing authors' prose as an extension of their lives. ${ }^{5}$

The Funeral Party and Daniel Stein present an elaborated argument for tolerance as they narrate the lives (and then deaths) of their hybrid protagonists. Ethnic and religious diversity, however, has long been a mainstay of Ulitskaia's prose - her first novella, Sonechka (1992), depicts the trials of the meek eponymous heroine. Sonechka's husband is the artist Robert Viktorovich, for whom marriage is the latest twist in a life where he has changed his faith, friends, and citizenship - unwisely returning to the USSR from France in the 1930s, he is imprisoned and meets his future spouse following his release. ${ }^{6}$

In another early work, the short story "Gulia," the protagonist of the same name has an affair with a younger man, an encounter that is just another surprise in a life including the gulag and exile. Now, decades later, the protagonist freely celebrates all the possible holidays her Polish-Russian ethnicity and Soviet citizenship provide. ${ }^{7}$ For Ulitskaia hybridity provides a multiplicity of viewpoints. In the play My Grandson Veniamin (2008), the dominating Jewish mother Esfir' believes she has found a bride for her son. The fiancée, Sonia, is the last remnant of the Jews who survived the Nazi massacre in Bobruisk. Esfir' is not privy to her daughter-in-law's innocent secret: Sonia was adopted from an orphanage, and later chose to have herself labeled "Jewish" in her passport out of love for the mother who had raised her. ${ }^{8}$ Ethnicity and family can come from choice as well as biology.

One early (and astute) assessment of Ulitskaia's works noted that the author's focus on the family is often refracted through Jewish and "Eastern" characters, since their sense of kinship is especially strong. ${ }^{9}$ The novel Medea and Her Children (1996) amplifies this discussion, presenting a maternal character whose hybrid identity is inseparable from the multiethnic Crimea that is her home.

and the recent horrors of the Second World War made tolerance seem less an abstraction than a prerequisite for humanity's survival. See Karl Popper, The Open Society and its Enemies (1945; reprint ed. Princeton, 1966), 1:235, viii-ix.

${ }^{5}$ Judith Kornblatt, Doubly Chosen: Jewish Identity, the Soviet Intelligentsia, and the Russian Orthodox Church (Madison, 2004), 15. On the problems of conflating author and fiction see Mikhail Bakhtin, "Forms of Time and of the Chronotope in the Novel," in The Dialogic Imagination: Four Essays by M. M. Bakhtin, ed. Michael Holquist, trans. Caryl Emerson and Michael Holquist (Austin, 1981), 253.

${ }^{6}$ Ulitskaia, Sonechka, Medeia i ee deti (Moscow, 1996), 281-82. For the first article-length discussion of Ulitskaia in English see Deuk-Jae Lee's analysis of Sonechka, "The Terrible Journey to Self-Identification," Rusistika, no. 17 (1998): 31-34.

${ }^{7}$ Liudmila Ulitskaia, "Gulia," Bednye, zlye, liubimye (Moscow, 2002), 86, 93-94. Iasmina Voivodich insightfully describes the significance of Gulia's various celebrations in "Chto otmechaet Gulia? O prazdnikakh v proizvedeniiakh Liudmily Ulitskoi," Russian Literature 62 (July 2007): 114.

${ }^{8}$ Ulitskaia, Moi vnuk Veniamin, Russkoe varen'e i drugoe (Moscow, 2008), 202, 211.

${ }^{9}$ Tat'iana Kazarina, "Bednye rodstvenniki," Preobrazhenie, 1996, no. 4:171. 
Medea Mendez had the maiden name of Sinoply and was ... the last pure-blooded Greek of a family settled since time immemorial on the Tauride coast, a land still mindful of its ties with Ancient Greece. ... The other Tauride Greeks of Medea's generation had either died or been deported, but she had lived on in the Crimea by the grace of God, as she supposed, but partly no doubt also because of the Spanish surname bequeathed by her late husband, a jolly Jewish dentist with vices which were minor but not insignificant, and virtues which were great but meticulously concealed.

A Russian-speaking Greek living in what will later become independent Ukraine, Medea's hybrid ethnicity is mirrored by the Jews, Russians, Armenians, Lithuanians, Ukrainians, and Tatars among her friends and relations - childless herself, she becomes a mother figure because of the everyday tolerance of her home. ${ }^{10}$ For Medea kinship is an elastic concept, embracing strangers as well as blood relatives.

As Medea and Her Children illustrates, for Ulitskaia family is a microcosm of humanity. The Funeral Party and Daniel Stein expand on this philosophy as they depict how respect for difference has the potential to heal the historical wounds of ethnic and secular strife. However, the two works also demonstrate the extent to which ethnic or religious belonging can become a dangerous delusion without tolerance.

\section{INTOLERANCE AND THE LESSONS OF THE PAST}

Twentieth-century Russian history, a major theme in Ulitskaia's works, leaves little doubt that the price of otherness is disastrous. The fate of those who are ethnically, politically, or sexually different is a leitmotif in her oeuvre-difference signals the potential for dissimulation, tantamount to treason throughout much of the Soviet era. ${ }^{11}$ For minorities such as Jews or Tatars, both figuring prominently in the author's narratives, otherness in the Soviet context (as well as its bloody precursor and unsettling aftermath) is not a matter of individual choice. It results instead from a judgment conferred by outsiders or the state; edicts such as the late-Stalinist campaign against "cosmopolitanism" or wartime mistrust of the Crimean Tatars quickly and often irrevocably changed the lives of these minorities. The lamentable consequences of such attitudes and their policies leave no doubt that ethnic and religious dogmatism create mandated intolerance: a condition where one authority-

\footnotetext{
${ }^{10}$ Ludmila Ulitskaya, Medea and Her Children, trans. Arch Tait (New York, 2002), 3. Tat'iana Rovenskaia argues that Medea's house is a home that moves in time, uniting the characters' lives as the novel progresses. See Rovenskaia's "Arkhetip doma v novoi zhenskoi proze, ili Kommunal'noe zhitie i kommunal'nye tela," Inoi vzgliad, 2001, no. 3:26.

${ }^{11}$ The Case of Kukotskii (Kazus Kukotskogo [Moscow, 2000]), for instance, illustrates Stalinism and its aftermath deforming the lives of characters such as Il'ia Gol'dberg, the hapless Jewish geneticist and dissident. This novel won Ulitskaia the 2001 Booker Prize. The consequences of intolerance also shape several of the short stories in Ulitskaia's The People of Our Tsar (2005). In one of them the autobiographical narrator sadly observes that she and her mother are hated in western Ukraine as "resort visitors, Russians (moskalei), and Jews." Identity is overdetermined, with presumed economic privilege (taking a vacation) linked to dislike of both occupiers (Russians) and a long-despised minority (Jews). See Ulitskaia, "O, Manon!" in Liudi nashego tsaria (Moscow, 2005), 325.
} 
whether anti-Semitic children in a grimy courtyard or the Central Committee of the Communist party-imposes identity on individuals.

Jews in the former Soviet space are the most visible victims of such policies, whose ferocity reached its peak with Nazi extermination efforts often aided by local authorities in the occupied territories. For a host of reasons, however, discussion of the Holocaust has been limited in Russian mainstream literature and national consciousness. ${ }^{12}$ Against this background Daniel Stein is a remarkable work if only for discussing the murder of Jews and their armed resistance in the ghetto of Emsk, a fictional stand-in for the Belarusian city of Mir. Using documentary style, Daniel Stein depicts how the Nazis exploited prewar hatred to turn various ethnicities against one another: first Poles and Belarusians helped the occupiers exterminate the Jews, then the Belarusians and Nazis dispatched the Poles.

This multiethnic focus raised the ire of nationalist critics - one decried the novel winning the Bol'shaia kniga Prize despite its alleged neglect of ethnic Russians and Orthodoxy. In claiming that Daniel Stein did not fit the definition of a "national" book because of its non-Russian focus, such critics signal that Russian citizenship equals Russian ethnicity and Orthodoxy, a guiding conservative conception of national identity. ${ }^{13}$ This stance is anathema for Ulitskaia, as it implies that there is little room for diversity in either Russian literature or its age-old mission to diagnose social ills. Daniel Stein chronicles the end result of such thinking: the destruction of imagined enemies, whether Jews or Slavs.

The vaunted Soviet friendship of peoples is the opposite extreme-an enforced ideological family ruled by Russian oversight. ${ }^{14}$ While the USSR was in many senses a multiethnic communal apartment on a grand scale, its involuntary cohabitation did not resolve tensions - it merely hid them, as the numerous post-Soviet conflicts have shown. In this sense one critic raises a key issue building on earlier assessments when he notes that Ulitskaia describes humanity as one large family — this is no utopian scenario, but an attempt to transform the Soviet "Great Family" and its post-1991 variant, the sometimes exclusionary spiritual kinship that Russian Orthodoxy provides. ${ }^{15}$ Indeed, for many of Ulitskaia's

\footnotetext{
${ }^{12}$ Two authors-Anatolii Rybakov and Vasilii Grossman - have depicted the Holocaust at great length in their prose. An account of this period also appears in the masterful but virtually ignored novel In Recent Memory (Svezho predanie [Tenafly, NJ, 1995]), written by I. Grekova (pseudonym of Elena Venttsel') in 1962. The manuscript remained unprintable for decades because of its link between Tsarist pogroms, Nazi genocide, and Stalinist anti-Semitism after 1945. For the novel's personages, ethnicity is something non-negotiable: a constant source of violence that destroys most of the characters. For one of the few discussions of In Recent Memory see Ol'ga Vronskaia, "Mama, ia zhid?" Literaturnaia gazeta 27 (1997): 3.

${ }^{13}$ Valentina Erofeeva, "Bol'shaia natsional'aia?!" Zavtra, December 19, 2007, http://www.zavtra.ru/denlit/ 136/74.html (last accessed February 17, 2009). On perceived connections between Orthodoxy and Russianness see Svetlana Ryzhova, "Tolerance and Extremism: Russian Ethnicity in the Orthodox Discourse of the 1990s," in Religion and Identity in Modern Russia: The Revival of Orthodoxy and Islam, ed. Juliet Johnson et al. (Aldershot, 2005), 68.

${ }^{14}$ Ulitskaia's autobiographical narrator discovers the tensions beneath this myth while in the Caucasus when listening to a litany of ethnic slurs from a neighbor (Ulitskaia, "Gudautskie grushi," in Liudi nashego tsaria, 250).

${ }^{15}$ Yuri Slezkine, "The USSR as a Communal Apartment, or How a Socialist State Promoted Ethnic Particularism," Slavic Review 53 (Summer 1994): 415. As Slezkine notes, this comparison comes from I. Vareikis and I. Zelenskii, Natsional'no-gosudarstvennoe razmezhevanie Srednei Azii (Tashkent, 1924), 59. On humanity as family see Andrei Arkhangel'skii, “Zhizn' ulitskaia," Ogonek, 2008, no. 9:47.
} 
characters, ethnicity is defined and applied by others. In Daniel Stein the former partisan Isaak Gantman, whose memoirs constitute one of the novel's numerous subplots, succinctly summarizes Jewish identity within this context: a Jew is someone whom gentiles deem Jewish — ethnicity is determined from above. ${ }^{16}$

Jews, however, also willingly estrange themselves from other ethnicities. In The Funeral Party, Leva Gotlib, the religiously conservative ex-husband of the lawyer Irina, cuts himself off from former acquaintances after becoming more dogmatic in his Judaism. As one critic observes, his distance from others resembles the self-imposed autism that has silenced Irina's teenage daughter, Tishort, who refuses to talk to adults. For Soviet Jewry and its diaspora, such isolation partially stems from past attacks and present discrimination, yet Ulitskaia's novella demonstrates that separation from others is a limiting solution regardless of circumstances. It is a retreat from tolerance, which involves the opposing perspectives Karl Jaspers has identified as central to communication. ${ }^{17}$

As suggested above, Russian Orthodoxy can also isolate those who use it to delimit their existence. In Daniel Stein, the fanatic monk Fedor, who has come to the Holy Land from the Russian provinces, is enraged after deciding that the Jews are keeping the secret of their religion from him. He destroys Daniel's church and is taken away to a psychiatric hospital, a fate that for one nationalist critic reveals Ulitskaia's dismissal of Orthodoxy. Faith per se is not the issue, as subsequent discussion will show. The problem is allowing this belief system to completely define one's mental horizons. The zealot all too easily confuses faith with an assuredness that makes exchanging ideas - and thus communicationimpossible. For Berlin, such certainty not only ends discussion but can lead to a "final solution" that promotes brutality in the name of righteousness, whether in a political or religious context. ${ }^{18}$

Gotlib and Fedor have embraced a false certainty precluding other viewpoints. Daniel Stein gives an even more extreme example, relating how the Jew Baruch Goldstein shoots Arabs at prayer before being killed by those who survive. All of this occurs within the borders of Israel, a state formed in response to the horrors of ethnic and religious intolerance. ${ }^{19}$ While the first half of the novel focuses on the Holocaust, the work provides ample evidence that the erstwhile victims could also become aggressors - a scenario feeding the fires of anti-Semitism. For Ulitskaia isolation opens the way to misunderstanding, enmity, and tragedy.

${ }^{16}$ Ulitskaia, Daniel' Shtain, 20.

${ }^{17}$ Mikhail Krutikov, "Opyt rossiiskoi evreiskoi emigratsii i ego otrazhenie v proze 90-kh godov," Diaspora, 2000, no. 3:221. On tolerance see Dar'ia Krasnoperova, "Zachem nam novoe slovo? Ili Zametki o tolerantnosti," Sankt-Peterburgskie vedomosti, March 4, 2003; and Karl Jaspers, "Communication: The Loving Struggle,” in Karl Jaspers: Basic Philosophical Writings (Athens, OH, 1986), 77-78.

${ }^{18}$ Ulitskaia, Daniel' Shtain, 327, 511-12. On Ulitskaia's supposed scorn for Orthodoxy see Anatolii Salutskii, "Kollazh na zadannuiu temu," Literaturnaia gazeta, 2007, no. 5:7. In the short story "Masha the Singer," pious Masha is accused of infidelity by her husband Ivan when she enjoys sex with him. His career in the Church is successful yet paradoxically estranges him from his family (Ulitskaia, "Pevchaia Masha," in Liudi nashego tsaria, 130, 135). On the dangers of ontological certainty and its political implementation by Nazis and Communists see Berlin, "The Pursuit of the Ideal," 201.

${ }^{19}$ Ulitskaia, Daniel' Shtain, 473. 


\section{DIVERSITY, COMMUNICATION, TOLERANCE}

Several prominent characters of mixed ethnicity stand out starkly against this forbidding background. Such hybrid personages are not new in Russian literature. ${ }^{20}$ What is innovative is how in Ulitskaia's writing many of them incorporate such diversity into a life that is not merely a function of faith or ethnicity: in The Funeral Party, for instance, Alik's Jewish identity plays almost no role until the last days preceding his death. Other characters deliberately highlight their hybrid status as a means of promoting tolerance, as is the case with the protagonist in Daniel Stein. Ulitskaia notes that Father Daniel is not trying to create a new religion with his masses reconciling Islam, Judaism, and Christianity_instead he strives to overcome ethnic hatred and misunderstanding. ${ }^{21}$

This effort amplifies what the author depicts as Alik's effort to foster an "atmosphere of reconciliation and love." Ulitskaia has long been interested in promoting understanding between Russia's numerous ethnic groups, leading her to edit a series of books published by the Institute of Tolerance, which continues the mission of the embattled Open Society Institute. This 2006 series introduces young readers to the food, dress, and everyday life of various social and ethnic groups throughout Russian history. ${ }^{22}$ As with depictions of hybrid characters who combine different backgrounds, these books combat prejudice-in this instance, Ulitskaia specifically addresses the generation that will shape the nation's future.

In discussing this series, the author invokes the rhetoric of tolerantnost' (tolerance), a crucial term for those interested in transforming Russia into an open civil society. This new term, its supporters argue, connotes respect and mutual understanding - terpimost ${ }^{\prime}$, the older Russian word signaling patience with difference, is not enough. In the post-Soviet context tolerance means equality between differing backgrounds and worldviews, as opposed to the condescension the majority may magnanimously show the minority. ${ }^{23}$

\footnotetext{
${ }^{20}$ In the twentieth century the most striking example is Kirill Liutov, a Jewish intellectual masquerading as a Christian-turned-atheist in the Red Cavalry (Konarmiia) stories of Isaak Babel.

${ }^{21}$ Ulitskaia, "Immeno eto propovedoval Iisus," interview with Vladimir Volodarskii, http://24.ua, December 8, 2007, http://www.bigbook.ru/smi/detail.php?ID=3825 (last accessed February 17, 2009). Nationalist critics assailed this effort, assuming Christianity and Judaism to be mutually exclusive - with the latter poised to swallow the former. See Erofeeva, "Bol'shaia natsional'naia?!"; and Andrei Vorontsov, "Oshibka patera Shtaina," Literaturnaia gazeta, 2007, no. 5:7.

${ }^{22} \mathrm{On}$ the creation and mission of the Institute of Tolerance see http://www.tolerinst.ru (last accessed February 17, 2009); and Ulitskaia, "Zanimatel'naia tolerantnost'," Weekend, 2008, no. 12, http://www.kommersant.ru/ doc.aspx?DocsID=873950 (last accessed February 17, 2009). For an earlier discussion of this project see Ulitskaia e-mail to Benjamin Sutcliffe, July 30, 2005 (in author's possession). The series includes four books published in 2006. For an overview with critical commentary see Irina Linkova, "Eta prekrasnaia tolerantnost'," BiblioGid, Kniga za knigoi, September 7, 2006 http://www.bibliogid.ru/news/tema/ulitskaya-tema (last accessed February 17, 2009).

${ }^{23}$ Krasnoperova, "Zachem nam novoe slovo?" 5 . On the difference between tolerance and patience see Iuliia Zelenina, "Tolerantnost' po-russki," Vecherniaia Moskva, November 16, 2005, http://www.vmdaily.ru/ article.php?aid=17711 (last accessed February 17, 2009). Ulitskaia revealed that supporters of tolerance still see these two terms as synonyms: while discussing her series promoting tolerantnost', she observed that today's youth should be more patient (terpimoi) with homosexuals ("Pisatel' Liudmila Ulitskaia: 'Nashi knigi o cheloveke, kotoryi ne takov, kak vy," Izvestiia, June 19, 2006).
} 
Several characters from the author's writing exemplify tolerance stemming from historically antagonistic cultural backgrounds. ${ }^{24}$ Medea's extended biological and figurative family in great part comes from her Greek roots and late Jewish husband; she embodies the diversity the novel ascribes to the Crimea. The narrative she unites is a sort of "encyclopedia of the family"- for Medea kinship is more important than affairs of state. ${ }^{25}$

Not surprisingly, ethnic diversity looms large in Ulitskaia's image of the Russian community in New York. The Funeral Party highlights the lives of Alik and Irina, whose personal convictions caused them to either emigrate or defect from the USSR. With one notable exception - their reaction to the 1991 coup-Soviet political repression is now a moot point for these Russian-Americans, who face the myriad problems confronting new immigrants. Irina Pierson (née Pirozhkova) is a former circus acrobat who, after working as an exotic dancer to pay for law school, now specializes in copyright issues. As the narrator approvingly notes, her skill as a tightrope walker greatly aided her life in emigration. Marrying Gotlib, she became a model Jewish wife, a role she abandoned (along with the marriage) for the simple but weighty reason of boredom. ${ }^{26}$ For Irina ethnicity is mutable, whether it be Russian, Jewish, or that most pliable of all, "American." Her travel, flexibility, and hard-earned salary exemplify the dream of her new homeland, which sees one's roots as far less important than one's future.

The Funeral Party is a site of convergent ethnicities that are striking even given Russian literature's long-standing fascination with the American melting pot. ${ }^{27}$ Alik's friends and former lovers are diverse to the point that one critic calls the variegated characters a new version of Noah's ark. Irina provides a secular analog to this image; she notes that Alik's friends are a vision of a Russia that never was - a utopian realm where Jewish doctors and Russian Orthodox artists converse and where African-Americans, whites, and Paraguayan street musicians can gather in the expansive confines of a Chelsea loft. The result is an expression of panhuman values, an environment within which no combination is shocking, yet where communication and understanding are more important than the mere fact of diversity. ${ }^{28}$

\footnotetext{
${ }^{24}$ This discussion does not address gays, another marginalized and often victimized group in Russian society. Two stories, "Angel" ("Golubchik") and "The Plug" ("Zatychka"), depict the plight of gay men imprisoned by the state. This fate recalls that of many ethnically hybrid characters in Ulitskaia's writing. For a more sustained discussion see Benjamin Sutcliffe, "Imagining the Violent State in Late- and Post-Soviet Women's Prose," in New Women's Writing in Russia and East Central Europe: Gender, Generation, and Identities, forthcoming from Cambridge Scholars Publishing.

${ }^{25}$ Ulitskaia, Medeia i ee deti, 46-47, 43. On Ulitskaia and family see, among others, Arkhangel'skii, "Zhizn' ulitskaia," 47.

${ }^{26}$ Ulitskaia, Veselye pokhorony, 55, 62-64.

${ }^{27}$ For Fedor Dostoevsky's Underground Man America was an artificial conglomeration, with its Civil War indicating the inherent instability of this ersatz nation. Other authors have been attracted rather than repelled. Sergei Dovlatov's novella A Foreign Woman (Inostranka) is inconceivable without the ethnic vibrancy of New York. Ulitskaia uses the city's hidden communities and constant surprises as background for the story "Francis of Assisi: Two in One" ("Frantsisk Assizskii: Dva v odnom") in Liudi nashego tsaria.

${ }^{28}$ Maiia Karapetian, "Aristokraty dukha, brazhniki i bludnitsy: 'Legkoe dykhanie' geroev Liudmily Ulitskoi," Kul'tura 27 (1998): 10; Ulitskaia, Veselye pokhorony, 232. On Ulitskaia, panhuman values, and Jaspers see V. Ia. Skvortsov and A. I. Skvortsova, "Samobytie cheloveka v povesti Liudmily Ulitskoi 'Veselye pokhorony," Vestnik Volgogradskogo gosudarstvennogo universiteta, Ser. 2, Filologiia, zhurnalistika 5 (2000): 110.
} 
Alik's motley company illustrates the potential for tolerance between religious as well as ethnic groups. As Alik slowly passes his last days in New York, he is helped by Mar'ia Ignat'evna, a Belarusian magical healer who blends herbs with prayers. She convinces Nina, Alik's second wife, that these salves and compresses will not work if the patient does not accept Christianity. ${ }^{29}$ This combination of pre-Christian medicine and Orthodox fervor comes from Eastern Slavs' long tradition of coexisting pagan and Christian practices, forming what Eve Levin succinctly terms "popular religion." 30 Russian Orthodoxy, Ulitskaia's narrative reminds us, is itself a combination of Byzantine rites and their appropriation by a population unwilling to give up its connection with the earth.

To appease Nina, Alik agrees to speak with an Orthodox priest - as long as a rabbi is also invited. This unforeseen demand is oddly fitting for Russian Orthodoxy, whose origins appear in the Primary Chronicle and its legendary account of Vladimir and his retinue conversing with representatives of Islam, Judaism, and the Eastern and Western churches. In the Primary Chronicle these consultations end as they must from the viewpoint of Kievan Rus': the Prince scornfully dismisses all faiths except for that of Constantinople. In Ulitskaia's novella the choice is not so simple, comprising one of the most remarkable scenes in Russian literature.

After the Sabbath has ended, Israeli Reb Menashe hurries to Alik's loft, only to find Father Viktor already there - the Orthodox priest is emerging from a successful yet troubling discussion with Alik. Irina is responsible for this uniquely awkward encounter; because of her many years spent away from Gotlib and Judaism, she has forgotten that the Jewish holy day ends at sundown. Gotlib, accompanying Menashe, sees Irina and Tishort for the first time since the divorce, just as, the narrator observes, Menashe is about to have his first conversation with a priest. ${ }^{31}$ The meeting of two historically antagonistic religions is contextualized as renewing friendship and coming to terms with the past, an apt image for the uneasy relationship between Judaism and Christianity.

Dialogue structures this scene, which exemplifies the divergent viewpoints Berlin and Jaspers pair with communication and tolerance. Alik has decided to be baptized, yet the priest is unsure of this step. The uncertainty Father Viktor has shown from the beginning reassures Alik. The cleric knows he is not a born priest; lacking any tinge of certainty, his interaction with the dying man is more human than instructive. In a strange but comforting image of the Eucharist, he feeds Alik a margarita through a straw (the artist is almost completely paralyzed). As one critic notices, throughout their conversation the rhythmic sounds of the Paraguayan street musicians act as a third voice. ${ }^{32}$ This third, pagan traditionalready evident in Mar'ia Ignat'evna's herbs-appears again as Alik speaks with two representatives of monotheistic religions.

\footnotetext{
${ }^{29}$ Ulitskaia, Veselye pokhorony, 24.

${ }^{30}$ Eve Levin, "Dvoeverie and Popular Religion," in Seeking God: The Recovery of Religious Identity in Orthodox Russia, Ukraine, and Georgia, ed. Stephen Batalden (DeKalb, 1993), 29.

${ }^{31}$ Ulitskaia, Veselye pokhorony, 71, 99, 122.

${ }^{32}$ Ibid., 96, 94, 93, 89; Iuzbashev, "L. Ulitskaia: Veselye pokhorony." Much critical debate has centered on dialogue in a Bakhtinian sense and diversity issues - see, for instance, Bakhtin and Otherness, guest eds. Robert Barsky and Michael Holquist, Discours social/Social Discourse (1991).
} 
Other critics have been far less perceptive in responding to this scene. Il'ia Kirillov is outraged by the "tactless" mention of the rabbi sitting on the bench still warm from Father Viktor's buttocks after the priest has left Alik's room. ${ }^{33}$ This moment is important, but not for the superficial reason Kirillov cites. Instead, this detail signals a basic human (as opposed to merely physiological) similarity between Christianity and Judaism. As Helena Goscilo has noted, Ulitskaia's oeuvre benefits from honest but not outré descriptions of the body, implying that the physical, spiritual, and erotic all have a place in life. ${ }^{34}$ While Kirillov is angered by Ulitskaia's naturalistic framing of the interaction of these religions, The Funeral Party shows that spirituality cannot exist without physiology. Reb Menashe astutely perceives this relationship between body and soul. At first shocked by the nearly naked women in Alik's stifling loft, he then concedes that there is something edenic and innocent about them. ${ }^{35}$

Speech, as well as the body, connects people. Both Viktor and Menashe converse with Alik in a foreign language; in the priest's case, he speaks the careful Russian of a firstwave emigrant, while the rabbi and artist speak in English. ${ }^{36}$ For Menashe and Alik the discussion is actually a series of alternating questions, accessing the subconscious heritage of Judaism uniting the scholar and artist. The rabbi presents Alik with three choices: the artist can remain a "captive child" (a Jew raised without Judaism), convert to Christianity, or become a Jew (by formally accepting Judaism). The final choice is a continuation of the status quo: Reb Menashe concludes that the artist should remain a "captive," that is, a Jew without Judaism, as he was before. ${ }^{37}$ This non-resolution, as well as Alik speaking to the rabbi after having decided to become a Christian, tells the reader that this dialogue is an exchange of ideas and not an imposition of faith.

This conversation exemplifies the tolerance imperative for modern civil society. Echoing Berlin and Jaspers, Ingrid Creppell notes how tolerance uses language as "a tool to bring about acts of accommodation. But it is also itself the embodiment of accommodation, that is, we use words rather than force to relate to one another." ${ }^{38}$ Communication necessarily involves hearing out opposing viewpoints. Speaking — and reading — substitute for coercion as The Funeral Party and Daniel Stein present conflicting viewpoints.

Even in the best of cases, hybridity has its challenges. In the autobiographical short story "My Favorite Arab" (2005), the narrator is at a conference in Paris when she is asked to assess how Russians perceive perestroika: "In general, I am not representative, and can't represent anyone except myself, since by culture I am Russian, by blood—Jewish, and by

\footnotetext{
${ }^{33}$ Ulitskaia, Veselye pokhorony, 97; Il'ia Kirillov, “'Kolbasa kosy’ Liudmila Ulitskoi,” Zavtra, August 8, 2000, http://www.zavtra.ru/denlit/044/42.html (last accessed February 17, 2009).

${ }^{34}$ Helena Goscilo, "Introduction," in Present Imperfect: Stories by Russian Women, ed. Ayesha Kagal and Natasha Perova (Boulder, 1996), 2.

${ }^{35}$ Ulitskaia, Veselye pokhorony, 106.

${ }^{36}$ Ibid., 108. Rosanna Giaquinta, "V seniakh smerti: Limb L. Ulitskoi," in XX vek i russkaia literatura: Alba Regina Philologiae. Sbornik nauchnykh statei, ed. Iu. L. Troitskii (Moscow, 2002), 272.

${ }^{37}$ Ulitskaia, Veselye pokhorony, 111-13; Krutikov, "Opyt rossiiskoi evreiskoi emigratsii i ego otrazhenie v proze 90-kh godov," 220.

${ }^{38}$ Ingrid Creppell, Toleration and Identity: Foundations in Early Modern Thought (New York, 2003), x. For Berlin, opposing arguments should be "intelligible" to the careful listener, who rejects some opinions yet tries to understand their origins ("The Pursuit of the Ideal," 199).
} 
faith-[Orthodox] Christian." ${ }^{39}$ For the narrator these are distinct facets of a hybrid identity, yet there is no inherent contradiction, only the weight of historical misunderstanding.

The author's works reveal that individual experience and beliefs are more important than being "representative." "My Favorite Arab" contradicts Reb Menashe's definition of Jewishness as based on not being a "captive child." Exclusion as a precept of ethnicity has terrifying implications; this formulation was also used by the Nazis to divide the human (Aryan) from the not-quite-human (for example, Jews and Slavs). Ulitskaia also suggests that such thinking denies the role of individual choice in negotiating one's own identity. Ironically, the rabbi's definition of Alik as a non-Jew follows the same logic as the Nazis who murdered Daniel's Germanophile father precisely because of his Jewish ancestry. Imposing ethnic or religious identity without considering the wishes of the individual is an act of mandated intolerance and ontological violence with very real consequences. ${ }^{40}$ Father Viktor insinuates that societal definitions of a person's ethnic and religious identity are relevant for the rabbi. Showing his familiarity with Israeli culture, the priest sympathetically speculates that those who do not appreciate Reb Menashe's research on Islamo-Judaic architecture may see the rabbi as a traitor to the cause of Israel..$^{41}$ Reb Menashe, Alik, and Daniel's father all face the threat of an identity imposed by others within the interlocked history of Judaism, Christianity, and Islam.

Alik resists external definitions of religion; it is Nina's baptism of him while he is unconscious that concludes the dialogue with Father Viktor and Reb Menashe. ${ }^{42}$ His wife's action, while taking place in multiethnic New York, hints at another geographical referent: Jerusalem is the underlying locus for the discussion between rabbi, priest, agnostic, and wife/baptizer. ${ }^{43}$ This sacred city of Jews, Christians, and Muslims is the metaphorical locale for the ongoing dialogue between the religions of The Funeral Party and Daniel Stein, symbolizing both ongoing division and the potential for unity.

Daniel is the epitome of religion and tolerance in Ulitskaia's writing. The relationship between Judaism and Christianity (and to a lesser extent, Islam) has received much attention, including invective from outraged critics representing the religions depicted in the novel. ${ }^{44}$ Such assessments, however, willfully ignore the fundamental idea of this work, a message voiced first and more hesitantly by Father Viktor in The Funeral Party. Discussing with Alik the dying man's reluctance to convert, the priest challenges the artist's putative lack of faith.

There are practically no non-believers. It's just a psychological cliché you brought over with you from Russia. I assure you there are no non-believers, particularly among artistic people. The nature of faith varies - the greater the intellect, the more complex the form it takes. There's also a form of intellectual chastity

\footnotetext{
${ }^{39}$ Ulitskaia, "Moi liubimyi arab," in Liudi nashego tsaria, 269.

${ }^{40}$ Ulitskaia, Daniel' Shtain, 36.

${ }^{41}$ Ulitskaia, Veselye pokhorony, 122.

${ }^{42}$ Ibid., 218-19.

${ }^{43}$ Giaquinta, "V seniakh smerti: Limb L. Ulitskoi," 278; Krutikov, "Opyt rossiiskoi evreiskoi emigratsii i ego otrazhenie v proze 90-kh godov," 220.

${ }^{44}$ Ulitskaia, "Immeno eto propovedoval Iisus."
} 
(tselomudriia) which won't allow anything to be discussed or articulated. We're surrounded by the most vulgar forms of primitive religiosity, and it's hard to bear. $^{45}$

Father Viktor's discourse falters and contradicts itself: first "there are practically no non-believers," and then "there are [simply] no non-believers, particularly among artistic people." The act of describing faith strengthens the priest's convictions, yet still allows for the existence of other ideas, a trait that along with a lack of certainty helps to sway the artist. As with ethnicity, the outward marker (Christianity, Judaism) is far less important than what lies beneath (belief, in the broadest spiritual sense). Father Viktor, no stranger to the problems of Russia's oppressed Jewish minority, further distinguishes true spirituality from its crass manifestations, which tempt people into non-belief (the "psychological cliché" of atheism). His explanation, while recalling the ecumenical unity of many "progressive" Western denominations, evokes a fundamental Christian dogma: humanity is fallible in its interpretation of God, but God is not. Corrupt manifestations of this spirit-for example, the Orthodox Church's veiled and explicit anti-Semitism-reflect human weakness, not divine will.

Daniel Stein develops the theme of faith as a variegated concept. Ulitskaia had first wanted to translate into Russian a book dealing with Oswald Rufeisen, a Jew who organized resistance to Nazi genocide, converted to Catholicism, and emigrated to Israel, where, having taken the name Father Daniel, he delivered a liturgy reconciling Judaism, Islam, and Christianity. ${ }^{46}$ Instead, she produced an astounding fictionalized history of interviews, letters, newspaper articles, and other documents. Together they recount how Daniel Stein, called "Dieter" by his father, hides in occupied Lithuania and Belarus, eventually working first for the Belarusian police, and then for the Gestapo as an interpreter. This hybrid status, a result of Dieter/Daniel having absorbed Polish and German as well as Yiddish culture, enables him to survive and alert the Jewish resistance of upcoming Nazi attacks. His career ends shortly after he helps three hundred Jews escape from the ghetto in Emska Jew informs on him, and the cultured Gestapo officer in charge of Daniel allows him to escape. ${ }^{47}$ The sophisticated German Reinhold is repeatedly contrasted with the drunken anti-Semite heading the Belarusian police-such humanization of the enemy, while not new in the context of post-Soviet culture, reiterates the destabilization of ethnic stereotypes in Ulitskaia's corpus. ${ }^{48}$

While hiding from the Germans in the attic of a Catholic convent in Emsk, Stein reads the New Testament and resolves the dilemma that has threatened his faith:

\footnotetext{
${ }^{45}$ Ulitskaya, The Funeral Party, trans. Cathy Porter and Arch Tait (New York, 1999), 47; Ulitskaia, Veselye pokhorony, 90.

${ }^{46}$ Ulitskaia, Daniel' Shtain, 122-23; “Triumfal'Inoe shestvie 'Danielia Shtaina," Kul'tura 27 (December 2007), http://www.bigbook.ru/smi/detail.php?ID=3934 (last accessed February 17, 2009).

${ }^{47}$ Ulitskaia, Daniel' Shtain, 101, 177, 207. On Oswald Rufeisen see Nechama Tec, In the Lion's Den: The Life of Oswald Rufeisen (New York, 1990).

${ }^{48}$ For discussion of the humanized enemy in post-Soviet depictions of the Great Patriotic War see Stephen Norris, "Guiding Stars: The Comet-Like Rise of the War Film in Putin's Russia: Recent World War II Films and Historical Memories," Studies in Russian and Soviet Cinema 1:2 (2007): 163-91.
} 
Where was God when they shot five hundred people from the Emsk ghetto? Where is God in all those experiences that my people are going through? What do we do with divine justice?

And then it was revealed to me that God was there with those who suffered. God can be only with those who suffer and never with the murderers. He was killed together with us. The god suffering together with the Jews was my God. ${ }^{49}$

The priest relates this experience during a 1990 discussion about the Holocaust with German schoolchildren in Freiburg, thus placing his conversion within a dialogue promoting understanding between faiths and cultures..$^{50}$ Empathy and divine mercy brought Daniel to Christianity — his god is one who embraces diversity, a fitting theology for Ulitskaia's works with their ethnic and religious variety. Daniel converts to Christianity because he has found what Nina has to provide on Alik's behalf: faith in a higher power that brings only tolerance and love, not hatred and strife. It is appropriate that this lesson is shared with the sons and daughters of the war generation who were both the aggressors and then victims of a conflict that devastated and divided Germany.

After converting to Christianity and becoming a Carmelite, Daniel makes his way to Israel. There, like his historical counterpart Rufeisen, he establishes a parish promoting reconciliation between the three religions that claim the Holy Land. Ecclesiastical authorities repeatedly censure him for masses that diverge from Catholic doctrine; in a scene that a less-skilled author could not present as credible, he has an audience with Pope John Paul II. This former friend from Poland heeds Daniel's call for Roman Catholics to repent for past persecution of the Jews. ${ }^{51}$ The conversation between Daniel and the Pope is important enough to risk violating the believability of the narrative-in Daniel Stein, however, the improbable twists and turns of its protagonist's life make even this unlikely scenario plausible.

On the fiftieth anniversary of the escape from the Emsk ghetto, Daniel conducts mass in the same Catholic church where he once hid before eventually finding his way to the convent and Christianity. ${ }^{52}$ The service marks both personal and collective commemoration; the mass is the logical conclusion of the idea of celebration in earlier Ulitskaia works such as "Gulia." The religious ceremony stresses unity while recalling the danger of subordinating togetherness to the false certainty of ethnic supremacy and faith-based intolerance.

\section{ULITSKAIA'S NARRATIVES OF TOLERANCE}

Daniel and Alik show that belief transcends religion; likewise, ethics are far more important than dogma. Ulitskaia's works were published when the Westerner/Slavophile debate had emerged from its Soviet hibernation. The re-formation of Russian national identity often took the form of "negative solidarities" resulting from a search for ethnic and ideological

${ }^{49}$ Ulitskaia, Daniel' Shtain, 229.

${ }^{50}$ In 1991, Patriarch Aleksei II made an analogous statement of tolerance when he condemned anti-Semitism before an assembly of rabbis in New York. See Ryzhova, "Tolerance and Extremism," 77; and Aleksei II, "Vashi proroki-nashi proroki," Moskovskie novosti (January 26, 1992): 24.

${ }^{51}$ Ulitskaia, Daniel' Shtain, 365-66.

${ }^{52}$ Ibid., 431-33. 
enemies - conservative author Viktor Astaf'ev purportedly labeled The Funeral Party "a shame." ${ }^{53}$ Given this context, Ulitskaia's shift away from enmity and isolation toward tolerance and engagement is a hopeful sign for post-Soviet culture.

Religious unity is not a panacea in her prose. However, as Father Viktor notes, nonbelievers are a rarity. Daniel echoes and expands this idea, showing how his narrative broadens and deepens the discussion in The Funeral Party. For the Catholic priest, as he states during his last discussion with the schoolchildren in Freiburg, faith is virtually everywhere. When asked by the (presumably Muslim) girl Fatima Adashi about his attitude toward those who do not believe, he notes:

Dear Fatima! I have to admit that in my life I have not met nonbelievers. Let's say, I have met almost none. Most people, besides those who fully and without reservation accept a faith chosen by them or passed on from their parents, have a conception of a Higher Power, that Prime Mover (Dvigatele mira) that we believers call the Creator. ${ }^{54}$

The fact that this exchange occurs between a Muslim and a Jewish convert to Christianity is not a coincidence. Within this framework Daniel clarifies that for some the "idea" that generates faith may be small (belief in UFOs, vegetarianism) or large (communism, fascism). This set of examples changes what at first seems a simplistic formulation about faith uniting humanity. As he adds in the same conversation, one can make any idea "into a god"; for Daniel it is necessary for faith to be grounded in acceptance of others, whether this be the Israeli state embracing its Christian and Muslim citizens, or Christians' need to reconcile themselves with their Jewish neighbors. Tolerance is itself a form of belief, as the priest makes clear when recalling a doctor whose avowed atheism was superseded by "irreproachable service to his patients." ${ }^{55}$ This belief, however, does not preclude othersit welcomes them as varying manifestations of its own credo and avoids the extremist certainty Berlin fears.

Faith takes many forms but appearance is less important than essence. Daniel Stein goes to great lengths to prove this, devoting much of the latter portion of the sometimes rambling novel to the historical changes dividing the early Church from its Judaic heritage. Two of the work's numerous subplots depict a German Catholic in love with an Arab Christian and the attempts of both the Carmelite hierarchy and Israeli state to make Daniel conform to their dicta - these strands intersect in Daniel, who personifies the harmonious coexistence of opposites.

Communication with the perceived other-a key component of tolerance- is central to Ulitskaia's writing. Sometimes the need for this interaction is implicit, as when Medea

\footnotetext{
${ }^{53}$ Ryzhova, "Tolerance and Extremism," 66. On Astaf'ev's comments see Mariia Remizova, "Grandes dames proshedshego sezona," Kontinent 112 (2002), http://magazines.russ.ru/continent/2002/112/remiz.html (last accessed February 17, 2009).

${ }^{54}$ Ulitskaia, Daniel' Shtain, 465

${ }^{55}$ Ibid. Ulitskaia has already depicted such a doctor-the protagonist in The Case of Kukotskii. Pavel Alekseevich is a confirmed "materialist, not tolerating any mysticism," who nonetheless sacrifices his health for patients and attempts to protect friends during Stalinism. This Christian model, however, is complicated
} 
remembers her brothers: in the Civil War one was killed by the Reds and a second by the Whites, while during the Great Patriotic War a third was murdered by the Nazis and a fourth by the Soviets. At other times the need for communication is obvious, as with the discussions between Alik, Father Viktor, and Reb Menashe. Indeed, as the rabbi and dying man trade questions, something extraordinary happens: "In their joking conversation everything was beneath the surface; both understood this, and their banter brought them to the serious point which occurs when people connect, a connection which leaves an indelible trace. ${ }^{156}$ It is this interaction that binds The Funeral Party and its seemingly mismatched characters together.

Connections also make these two works by Ulitskaia novels. In Daniel Stein dialogue in particular both decenters the plot and brings it together. Ulitskaia's autobiographical frame narrator, whose comments end each of the novel's five major segments, sees the work as impossible to complete, complaining that it is less a novel than a collage. One critic identifies this as a weakness, with the numerous incorporated documents revealing poor writing and a lack of central purpose. This assessment shows a fundamental failure to grasp the novel's underlying principle, namely, the importance of considering opposing ideas instead of upholding a single preordained truth. Grappling with the interviews, transcripts, and often conflicting reports that dominate the work, the reader must confront the same contrasting ideas that Daniel incorporated into a manifesto of unity through tolerance. In this way the novel models the benefits of diversity at the level of structure as well as theme. ${ }^{57}$

It is specifically this heterogeneity that defines the novel - a genre formed by the clash of voices and internal narratives, as when Daniel Stein and The Funeral Party move from one character's opinions to those of another. Appropriately enough, it is the discussion between Daniel and the German schoolchildren that provides one of the anchors for the plot: these talks link the older and younger generations together in an effort to avert future genocide, a task only possible through mutual acceptance and the exchange of ideas. In a similar vein, the talk between Reb Menashe and Father Viktor suggests that the holy men have discovered a previously unacknowledged duty to promote understanding. In both works the act of engagement - via words instead of violence — exemplifies how language gives form to tolerance. ${ }^{58}$

For Ulitskaia the diverse community gives life meaning, whether this group is Daniel's multiethnic parish or the lovers, friends, and chance acquaintances helping Alik mark his last days. These communities arise from a kinship that may be biological, religious, or the simple recognition of an overarching human family. What holds these groups together is

by the physician's unstinting effort to legalize abortion, effectively banned in the USSR from 1936 to 1955 . Clearly Pavel Alekseevich is still a believer in Daniel's sense. The form of faith is less important than its manifestation, that is, its effect on others (Ulitskaia, Kazus Kukotskogo, 15, 72).

${ }^{56} \mathrm{On}$ the necessity for engagement as a part of tolerance see Popper, The Open Society and its Enemies 1:235. Jaspers sees this action as key to human interaction ("Communication: The Loving Struggle," 77). See also Ulitskaia, Medeia $i$ ee deti, 32; and idem, The Funeral Party, 57.

${ }^{57}$ Ulitskaia, Daniel' Shtain, 241, 469: Salutskii, "Kollazh na zadanniui temu," 7.

${ }^{58}$ Bakhtin, The Dialogic Imagination, 40, 262. 
tolerance: choosing to coexist with those whose backgrounds oppose our own. In Ulitskaia's writing difference and tolerance are mutually dependent, allowing each individual to exist within a world where unity is chosen, not coerced. 